\title{
Phytochemical constituents and synergistic activity of Olea Europaea plant extracts against some human disease causing species
}

\begin{abstract}
Medicinal plants are extensively used for the cure of different infectious diseases. Infectious diseases caused by bacteria have a large impact on public health. This study aimed to determine the in vitro antibacterial activity of the medicinal plants Olea europaea against the bacterial strains associated with infectious diseases. Extracts of Olea europaea were tested for their antibacterial activity against three bacterial species includes gram-positive bacteria (Staphylococcus aureus) and gram-negative bacteria (Escherichia coli and Pseudomonas aeruginosa) using the microdilution method. In the present study we found that methanolic extract of $O$. europaea in combination of ampicillin shows higher zone of inhibition and lesser MIC values as compared to methanolic extract of leaves of $O$. europaea or ampicillin when used alone. Synergistic antimicrobial activity was found when methanolic extract of leaves of $O$. europaea was used in combination with ampicillin against against $E$. coli and $P$. aeroginosa $(\mathrm{FIC} \leq 0.5$ ). Partial Synergistic antimicrobial activity was observed against $S$. aureus. Methanolic extract of stem and roots of $O$. europaea in combination with ampicillin gave indifferent antimicrobial results $(\mathrm{FIC}=1.0-4.0)$. Benzene extract of the leaf, stem and root of $O$. europaea in combination with ampicillin showed indifferent antimicrobial results (FIC $=1.0-4.0$ ). Aqueous extract of leaves of $O$. europaea in combination with ampicillin showed Partial Synergistic antimicrobial activity against $E$. coli, P. aeroginosa and $S$. aureus. $(\mathrm{FIC}=0.5-1.0$ ). Aqueous extract of the stem and root of $O$. europaea in combination with ampicillin showed indifferent antimicrobial results $(\mathrm{FIC}=1.0-4.0)$. This study indicates clear evidence supporting the traditional use of Olea europaea in treating infectious diseases related to bacteria.
\end{abstract}

Keywords: Olive; Microorganism; Antibiotic; Diseases; Solvent extraction
Volume 4 Issue 5 - 2017

\author{
Fatema shah,' Ziaul Hasan,' Kamal Uddin \\ Zaidi $^{2}$ \\ 'Department of Microbiology, Saifia College of Science, India \\ ${ }^{2}$ Biotechnology Pharmacology Laboratory, People's University, \\ India
}

Correspondence: Kamal Uddin Zaidi, Biotechnology Pharmacology Laboratory CSRD, Centre for Scientific Research \& Development, Peoples University, Bhopal, (MP) 462037, India, Email Zaidi.kama192@gmail.com

Received: November 12, 2016 | Published: April 18, 2017
Abbreviations: FIC, fraction inhibitory concentration; MIC, minimum inhibitory concentration; ZOI, zone of inhibition; $S$. aureus, staphylococcus aureus; E.coli, escherichia coli; P. aeruginosa, Pseudomonas aeruginosa; O. europaea, olea europaea

\section{Introduction}

The search for alternative antimicrobial compounds is an urgent area of biomedical research and extracts derived from plants have long held interest as potential sources of new therapeutic agents. The medicinal use of plants is probably as old as mankind. Plants have continued to be a valuable source of natural products for maintaining human health. Various medicinal plants have been used for years in daily life to treat disease all over the world. One of the remotest works in traditional herbal medicine is virikshayurveda, compiled even before the beginning of Christian era. ${ }^{1,2}$ Olea europaea plants have been shown to be a promising source of potent antimicrobial agents. Plant derived substances have recently become of great interest owing to their versatile applications. Medicinal plants are the richest bio-resource of drugs of traditional systems of medicine, modern medicines, nutraceuticals, food supplements, folk medicines, pharmaceutical intermediates and chemical entities for synthetic drugs. $^{3-5}$

Phenolic compounds in the olive fruits such as oleuropein, tyrosol, hydroxytyrosol, caffeic acid, gallic acid, syringic acid, p-coumaric acid, p-hydroxybenzoic acid, protocatechuic acid, quercetin, and luteolin show antimicrobial activity against viruses, bacteria, yeasts, and fungi. ${ }^{6-8}$ This study was designed at authenticated the traditional use of Olea europaea medicinal plants against human pathogenic bacteria, causing a number of human disease including Escherichia coli, Pseudomonas aeruginosa and Staphylococcus aureus by assess their in vitro antibacterial activity. Due to insufficient screening of the natural compounds and the limited understanding of their mechanism of action against the microorganism the need of the hour is to identify more and more natural compounds which exhibit synergistic behavior with the antibiotics.

\section{Materials and methods}

\section{Collection and identification of plant material}

Plant materials Olea europaea (Olive) were purchased from local market and were authenticated by Dr. S.S. Khan of Botany, Department Saifia Science College Bhopal. The voucher specimen no (J/R201) was deposited at the Herbarium of the Faculty of Botany Department, Saifia Science College Bhopal (M.P.) India

\section{Human pathogenic microorganisms}

Human disease causing bacteria; Escherichia coli (MTCC 739), Staphylococcus aureus (MTCC 96) Pseudomonas aeruginosa (MTCC 74) were procured from Institute of Microbial Technology, Chandigarh (IMTECH), India. These bacterial strains were then used for studying the antimicrobial efficiency.

\section{Preparation of plant extract}

The phytochemical constituents of the Olea europaea plant parts (leaf, stem, and root) were extracted in soxhlet apparatus using various 
solvents. ${ }^{9,10}$ Soxhlet extraction is used for separating components based on the difference in the solubility in the solvent. The powdered plant material $(50 \mathrm{gm})$ was placed in the soxhlet extractor flask. $500 \mathrm{ml}$ of the organic solvent was taken in the round bottom flask. The soxhlet extraction was carried out continuously at an appropriate temperature for 6-8 hrs, till colorless extract is collected in the extractor flask. The extract thus obtained was collected in collection bottles and was further subjected to concentration using Rotary vacuum evaporator. After soxhlet extraction the extracts obtained were filtered and then each of the extract was concentrated using rotary vacuum evaporator. The individual extracts were taken in round bottom flask which was heated at appropriate temperature on a water bath. The vapors of the solvent rise in the condenser and after condensation the solvent droplets was collected in the collecting flask. The resultant sticky mass was collected in the crucible. It was dried at a low temperature in the oven. The solid mass obtained was stored in a suitable volume of $10 \%$ dimethyl sulphoxide (DMSO) with a drop of Tween-20. Aqueous extract of the individual plant parts was prepared by decoction method. Filter paper packets of $50 \mathrm{gm}$ of the individual plant parts were prepared. These packets were place separately in $200 \mathrm{ml}$ of hot water contained in bottles. The extraction was carried out for $24 \mathrm{oC}$ with intermittent shaking. The extracts obtained were concentrated and dried. The dried mass obtained was stored in a suitable volume of $10 \%$ dimethyl sulphate (DMSO) with a drop of tween-20.

\section{Phytochemical analysis}

Chemical test were carried out to identify various constituents using standard method of Trease and Evans ${ }^{10}$ \& Harbone. ${ }^{11}$ Mayer reagent was prepared by dissolving 1.36 grams of mercuric chloride in $60 \mathrm{ml}$ of distilled water and 5 grams of potassium iodide in $20 \mathrm{ml}$ of distilled water. Both the above solution was mixed and volume of the reagent adjusted to $100 \mathrm{ml}$ by distilled water. $1 \mathrm{ml}$ of the plant extract was taken and few drops of mayer reagents were added. Formation of cream colour precipitate was confirms the presence of alkaloid. Fehling solution was prepared by dissolving 4.36 gram of copper sulphate in $50 \mathrm{ml}$ of distilled water and by dissolving 17.3 grams of sodium potassium tartarate and 5 gram of sodium hydroxide in $50 \mathrm{ml}$ of distilled water. Both the solution were mixed prior to use. $1 \mathrm{ml}$ of the extract were taken and few drops of fehling solution was added. Formation of red precipitate confirms the presence of carbohydrates and glycosides. Ferric chloride solution was prepared by dissolving 5 grams of ferric chloride in $100 \mathrm{ml}$ of $90 \%$ ethanol. 1 $\mathrm{ml}$ of extract was taken and few drops of ferric chloride solution were added. Formation of bluish black precipitate confirms the presence of phenolic compounds and tannins. Ninhydrin solution was prepared by dissolving 0.3 grams of ninhydrin in $100 \mathrm{ml}$ of ethanol. $1 \mathrm{ml}$ of extract was taken and few drops of ninhydrin solution were added and purplish pink colour confirms the presence of proteins and amino acids in extracts. Alkaline reagent was prepared by dissolving 10 grams of sodium hydroxide in $100 \mathrm{ml}$ of distilled water. $1 \mathrm{ml}$ of extract was taken and few drops of sodium hydroxide solution were added. Intense yellow colour confirms the presence of flavonoids. $1 \mathrm{ml}$ of the extract was taken and mixed with few drops of chloroform and few drops of sulphuric acids. A reddish brown colour confirms the presence of terpenoids. $1 \mathrm{ml}$ of the extract was taken and diluted with distilled water to $10 \mathrm{ml}$. Formation of stable foam confirms the presence of saponins. $1 \mathrm{ml}$ of the extract was mixed with $5 \mathrm{ml}$ of distilled water mixture was heated and to it was added $5 \mathrm{ml}$ of $1 \% \mathrm{HCl}$. Formation of red precipitate confirms the presence of phlobatanins. $1 \mathrm{ml}$ of the extract was taken and to it was added in $2 \mathrm{ml}$ of chloroform and $2 \mathrm{ml}$ of concentrated sulphuric acid. Formation of reddish brown layer at the interface confirms the presence of steroids.

\section{Assay of antimicrobial activity using disc diffusion method}

Disc diffusion method for antimicrobial susceptibility testing was carried out according to the standard method by Bauer et al. ${ }^{12}$ to assess the presence of antibacterial activities of the various samples. A bacterial suspension was prepared for each of bacteria used for the study. $1 \mathrm{ml}$ of the bacterial suspension was taken in sterile petriplate. To it was added molten nutrient agar media under aseptic conditions and mixed well. It was allowed to solidify for 1 hour to allow the bacteria to grow. These plates were used for sensitivity test. Whatman filter paper disc were impregnated with the samples and were placed on nutrient agar surface. Positive control plate was also prepared with standard antibiotic disc and negative control plate was prepared using DMSO. The plates were then incubated at $37 \mathrm{oC}$ for $24 \mathrm{hrs}$. After the incubation the plates were examine for zone of inhibition. The inhibition zones were measured using antibiotic zone reader scale.

\section{Determination of minimum inhibitory concentration (MIC)}

The minimum inhibitory concentration of the plant extracts, antibiotics and combination of plant extracts and antibiotics was determined by diluting the extracts in Nutrient broth to give concentration of $1024,512,256,128,64,32,16,8,4$ and $2 \mu \mathrm{g} / \mathrm{ml}$. $2 \mathrm{ml}$ of plant extracts, antibiotics and combination of plant extracts and antibiotics was added to the first tube containing $2 \mathrm{ml}$ of broth. The tube was shaken and $2 \mathrm{ml}$ transferred aseptically to the next tube containing the same quantity of broth. This was done until serial dilution was achieved in the last tube that is the tenth tube. Then 0.1 $\mathrm{ml}$ of the MTCC bacterial culture suspension was inoculated into each test tube and they were incubated at $37 \mathrm{oC}$ for 24 hours. The absorbance of the tubes was taken in UV-VIS spectrophotometer. The minimum inhibitory concentration was regarded as the lowest concentration of the extract that did not permit any visible growth when compared with the control tube.

\section{Calculate FIC and FIC Index}

A widely accepted method, to measure the effect of combination of plant extract and antibiotic is the fractional index. The fractional index is used to identify whether a combination therapy is synergistic, additive or antagonistic. The Inhibitory Concentration is determined using MIC measurements. The fractional Inhibitory Concentration Index ( $\sum$ FIC) is the sum of the FICS of each of the plant extract and antibiotics. ${ }^{13}$

\section{Calculations}

The FIC was calculated for plant extract and antibiotic as follows: The FIC was calculated for plant extract and antibiotic as follows:

Calculated the summation of FIC (SFIC) index for each combination as follows:

$$
\Sigma \text { FIC }=\text { FIC of Plant Extracts }+ \text { FIC of Antibiotics }
$$

\section{Results}

\section{Antibacterial activity of methanolic extracts with ampicillin}

The ZOI of the leaf extract against E.coli, P. aeruginosa and $S$. aureus was $18 \mathrm{~mm}, 18 \mathrm{~mm}$ and $14 \mathrm{~mm}$ respectively. The ZOI of the combination of leaf extract of O. europaea and ampicillin were $29 \mathrm{~mm}$, 
$27 \mathrm{~mm}$ and $25 \mathrm{~mm}$. The MIC of the leaf extract was $16 \mu \mathrm{g} / \mathrm{ml}, 32 \mu \mathrm{g} /$ $\mathrm{ml}$ and $128 \mu \mathrm{g} / \mathrm{ml}$ against $E$. coli, $P$. aeruginosa and $S$. aureus. The MIC of the combination of leaf extract of $O$. europaea and ampicillin were $2 \mu \mathrm{g} / \mathrm{ml}, 8 \mu \mathrm{g} / \mathrm{ml}$ and $16 \mu \mathrm{g} / \mathrm{ml}$ respectively. The ZOI of the stem extract against E.coli, P. aeruginosa and $S$. aureus was $1 \mathrm{~mm}, 0 \mathrm{~mm}$ and $8 \mathrm{~mm}$ respectively. The ZOI of the combination of stem extract of $O$. europaea and ampicillin were $24 \mathrm{~mm}, 22 \mathrm{~mm}$ and $23 \mathrm{~mm}$. The MIC of the stem extract was $128 \mu \mathrm{g} / \mathrm{ml}, 64 \mu \mathrm{g} / \mathrm{ml}$ and $32 \mu \mathrm{g} / \mathrm{ml}$ against $E$. coli, P. aeruginosa and S. aureus. The MIC of the combination of stem extracts of $O$. europaea and ampicillin were $16 \mu \mathrm{g} / \mathrm{ml}, 32 \mu \mathrm{g} / \mathrm{ml}$ and $16 \mu \mathrm{g} / \mathrm{ml}$ respectively. The ZOI of the root extract against E.coli, $P$. aeruginosa and $S$. aureus was $0 \mathrm{~mm}$. The ZOI of the combination of root extract of $O$. europaea and ampicillin were $23 \mathrm{~mm}, 22 \mathrm{~mm}$ and $23 \mathrm{~mm}$. The MIC of the root extract was $32 \mu \mathrm{g} / \mathrm{ml}, 32 \mu \mathrm{g} / \mathrm{ml}$ and $128 \mu \mathrm{g} / \mathrm{ml}$ against $E$. coli, P. aeruginosa and $S$. aureus. The MIC of the combination of root extract of $O$. europaea and ampicillin were $16 \mu \mathrm{g} /$ $\mathrm{ml}, 32 \mu \mathrm{g} / \mathrm{ml}$ and $32 \mu \mathrm{g} / \mathrm{ml}$ respectively (Table 1 ).

\section{Antibacterial activity of combined effect of benzene extracts with ampicillin}

The ZOI of the leaf Extract against E.coli, P. aeruginosa and $S$. aureus was $8 \mathrm{~mm}, 10 \mathrm{~mm}$ and $8 \mathrm{~mm}$ respectively. The ZOI of the combination of leaf extract of $O$. europaea and ampicillin were $24 \mathrm{~mm}$, $23 \mathrm{~mm}$ and $23 \mathrm{~mm}$. The MIC of the leaf Extract was $16 \mu \mathrm{g} / \mathrm{ml}, 64 \mu \mathrm{g} /$ $\mathrm{ml}$ and $256 \mu \mathrm{g} / \mathrm{ml}$ against E.coli, P. aeruginosa and $S$. aureus. The MIC of the combination of leaf extract of $O$. europaea and ampicillin were $8 \mu \mathrm{g} / \mathrm{ml}, 32 \mu \mathrm{g} / \mathrm{ml}$ and $32 \mu \mathrm{g} / \mathrm{ml}$ respectively. The ZOI of the stem extract against $E$. coli, $P$. aeruginosa and $S$. aureus was $0 \mathrm{~mm}$. The ZOI of the combination of stem extract of $O$. europaea and ampicillin were $24 \mathrm{~mm}, 22 \mathrm{~mm}$ and $23 \mathrm{~mm}$. The MIC of the stem extract was $32 \mu \mathrm{g} / \mathrm{ml}, 128 \mu \mathrm{g} / \mathrm{ml}$ and $256 \mu \mathrm{g} / \mathrm{ml}$ against E.coli, $P$. aeruginosa and $S$. aureus. The MIC of the combination of stem extract of $O$. europaea and ampicillin were $16 \mu \mathrm{g} / \mathrm{ml}, 32 \mu \mathrm{g} / \mathrm{ml}$ and $32 \mu \mathrm{g} / \mathrm{ml}$ respectively. The ZOI of the root extract against E.coli, P. aeruginosa and S. aureus was $9 \mathrm{~mm}, 0 \mathrm{~mm}$ and $0 \mathrm{~mm}$ respectively. The ZOI of the combination of root extract of $O$. europaea and ampicillin were $25 \mathrm{~mm}, 21 \mathrm{~mm}$ and $23 \mathrm{~mm}$. The MIC of the root extract was $64 \mu \mathrm{g} / \mathrm{ml}, 32 \mu \mathrm{g} / \mathrm{ml}$ and $64 \mu \mathrm{g} / \mathrm{ml}$ against E.coli, P.aeruginosa and S. aureus. The MIC of the combination of root extract of O. europaea and ampicillin were $8 \mu \mathrm{g} /$ $\mathrm{ml}, 16 \mu \mathrm{g} / \mathrm{ml}$ and $32 \mu \mathrm{g} / \mathrm{ml}$ respectively (Table 2 ).

\section{Antibacterial activity of combined effect of aqueous extracts with ampicillin}

The ZOI of the leaf extract against $E$. coli, $P$. aeruginosa and $S$. aureus was $14 \mathrm{~mm}, 15 \mathrm{~mm}$ and $9 \mathrm{~mm}$ respectively. The ZOI of the combination of leaf extract of O. europaea and ampicillin were $26 \mathrm{~mm}$, $25 \mathrm{~mm}$ and $22 \mathrm{~mm}$. The MIC of the leaf Extract was $64 \mu \mathrm{g} / \mathrm{ml}, 64 \mu \mathrm{g} /$ $\mathrm{ml}$ and $256 \mu \mathrm{g} / \mathrm{ml}$ against E.coli, P. aeruginosa and S. aureus. The MIC of the combination of leaf extract of $O$. europaea and ampicillin were $8 \mu \mathrm{g} / \mathrm{ml}, 16 \mu \mathrm{g} / \mathrm{ml}$ and $32 \mu \mathrm{g} / \mathrm{ml}$ respectively. The ZOI of the stem Extract against E.coli, $P$. aeruginosa and $S$. aureus was $9 \mathrm{~mm}, 0 \mathrm{~mm}$ and $8 \mathrm{~mm}$ respectively. The ZOI of the combination of stem extract of $O$. europaea and ampicillin were $24 \mathrm{~mm}, 22 \mathrm{~mm}$ and $23 \mathrm{~mm}$. The MIC of the stem extract was $64 \mu \mathrm{g} / \mathrm{ml}, 32 \mu \mathrm{g} / \mathrm{ml}$ and $32 \mu \mathrm{g} / \mathrm{ml}$ against $E$. coli, $P$. aeruginosa and $S$. aureus. The MIC of the combination of stem extract of $O$. europaea and ampicillin were $8 \mu \mathrm{g} / \mathrm{ml}, 16 \mu \mathrm{g} / \mathrm{ml}$ and $16 \mu \mathrm{g} / \mathrm{ml}$ respectively. The ZOI of the root extract against E.coli, $P$. aeruginosa and $S$. aureus was $0 \mathrm{~mm}$. The ZOI of the combination of root extract of O. europaea and ampicillin were $24 \mathrm{~mm}, 22 \mathrm{~mm}$ and $23 \mathrm{~mm}$. The MIC of the root Extract was $32 \mu \mathrm{g} / \mathrm{ml}, 128 \mu \mathrm{g} / \mathrm{ml}$ and $256 \mu \mathrm{g} / \mathrm{ml}$ against E.coli, P. aeruginosa and S. aureus. The MIC of the combination of root extract of O. europaea and ampicillin were $16 \mu \mathrm{g} /$ $\mathrm{ml}, 32 \mu \mathrm{g} / \mathrm{ml}$ and $32 \mu \mathrm{g} / \mathrm{ml}$ respectively (Table 3 ).

Table I Zone of Inhibition, Minimum Inhibitory Concentration and Fractional Inhibitory Concentration of Methanolic extract of leaf, stem and root of $O$. europaea $L$

\begin{tabular}{|c|c|c|c|c|c|c|c|c|c|}
\hline \multirow{3}{*}{ Plants material } & \multirow{2}{*}{\multicolumn{3}{|c|}{ Zone of inhibition ( $\mathrm{mm}$ ) }} & \multirow{2}{*}{\multicolumn{3}{|c|}{$\begin{array}{l}\text { Minimum inhibitory } \\
\text { concentration in } \mu \mathrm{g} / \mathrm{ml} \text { ( MIC ) }\end{array}$}} & \multirow{2}{*}{\multicolumn{3}{|c|}{$\begin{array}{l}\text { Fractional inhibitory conc. } \\
\text { FIC \& S FIC }\end{array}$}} \\
\hline & & & & & & & & & \\
\hline & E. coli & P. aeruginosa & S. aureus & E. coli & P. aeruginosa & S. aureus & E. coli & P. aeruginosa & S. aureus \\
\hline Leaf & 18 & 18 & 14 & 16 & 32 & 128 & 0.125 & 0.25 & 0.125 \\
\hline Ampicillin & 23 & 21 & 22 & 16 & 32 & 32 & 0.125 & 0.25 & 0.5 \\
\hline Leaf + Ampicillin & 29 & 27 & 25 & 2 & 8 & 16 & 0.25 & 0.5 & 0.625 \\
\hline Stem & - & - & 8 & 128 & 64 & 32 & 0.125 & 0.5 & 0.5 \\
\hline Ampicillin & 23 & 21 & 22 & 16 & 32 & 32 & 1 & 1 & 0.5 \\
\hline Stem + Ampicillin & 24 & 22 & 23 & 16 & 32 & 16 & 1.125 & 1.5 & 1 \\
\hline Root & - & - & - & 32 & 128 & 32 & 0.5 & 0.25 & I \\
\hline Ampicillin & 23 & 21 & 22 & 16 & 32 & 32 & I & I & I \\
\hline Root + Ampicillin & 23 & 22 & 21 & 16 & 32 & 32 & 1.5 & 1.25 & 2 \\
\hline
\end{tabular}

Table 2 Zone of Inhibition, Minimum Inhibitory Concentration and Fractional Inhibitory Concentration of Benzene extract of leaf, stem and root of $O$. europaea $L$

\begin{tabular}{|c|c|c|c|c|c|c|c|c|c|}
\hline \multirow{3}{*}{ Plants material } & \multirow{2}{*}{\multicolumn{3}{|c|}{ Zone of Inhibition ( $\mathrm{mm}$ ) }} & \multirow{2}{*}{\multicolumn{3}{|c|}{$\begin{array}{l}\text { Minimum inhibitory concentration } \\
\text { in } \mu \mathrm{g} / \mathrm{ml} \text { ( } \mathrm{MIC} \text { ) }\end{array}$}} & \multirow{2}{*}{\multicolumn{3}{|c|}{$\begin{array}{l}\text { Fractional inhibitory conc. } \\
\text { FIC \& S FIC }\end{array}$}} \\
\hline & & & & & & & & & \\
\hline & E. coli & P. aeruginosa & S. aureus & E. coli & P. aeruginosa & S. aureus & E. coli & P. aeruginosa & S. aureus \\
\hline Leaf & 8 & 10 & 8 & 16 & 64 & 256 & 0.5 & 0.5 & 0.125 \\
\hline Ampicillin & 23 & 21 & 22 & 16 & 32 & 32 & 0.5 & I & I \\
\hline Leaf + Ampicillin & 24 & 23 & 23 & 8 & 32 & 32 & I & 1.5 & 1.125 \\
\hline Stem & 0 & 0 & 0 & 32 & 128 & 256 & 0.5 & 0.25 & 0.125 \\
\hline Ampicillin & 23 & 21 & 22 & 16 & 32 & 32 & I & I & $\mathrm{I}$ \\
\hline Stem + Ampicillin & 24 & 22 & 23 & 16 & 32 & 32 & 1.5 & 1.25 & 1.125 \\
\hline Root & 9 & 0 & 0 & 64 & 32 & 64 & 0.125 & 0.5 & 0.5 \\
\hline Ampicillin & 23 & 21 & 22 & 16 & 32 & 32 & 0.5 & 0.5 & I \\
\hline Root + Ampicillin & 15 & 21 & 23 & 8 & 16 & 32 & 0.625 & I & 1.5 \\
\hline
\end{tabular}


Table 3 Zone of Inhibition, Minimum Inhibitory Concentration and Fractional Inhibitory Concentration of Aqueous extract of leaf, stem and root of 0 . europaea $L$

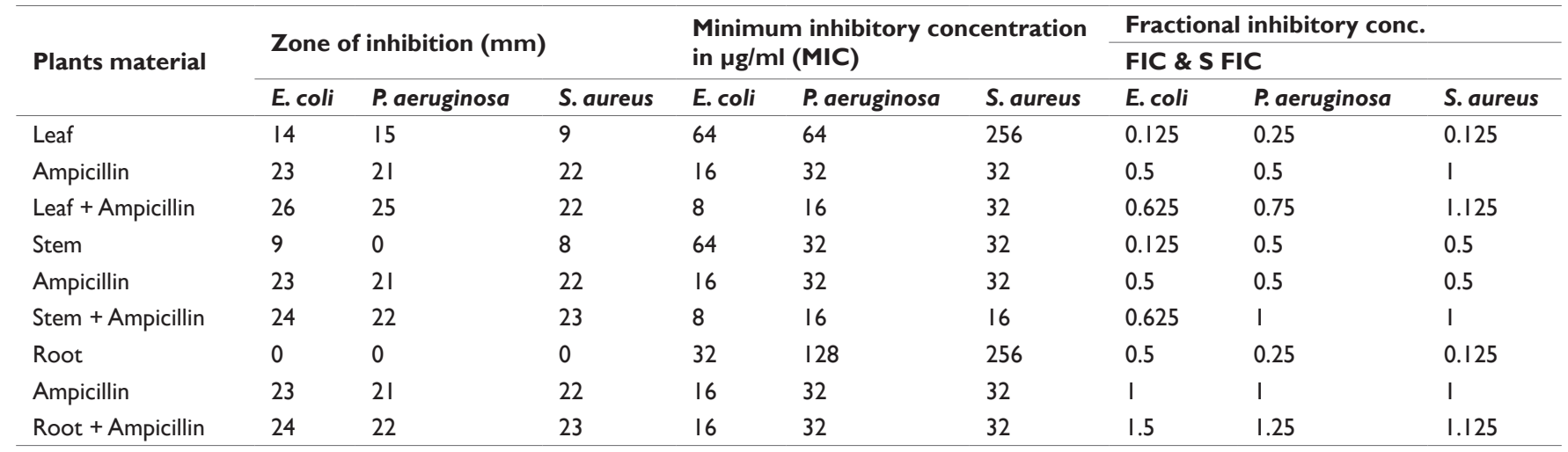

Table 4 Phytochemical constituents present in methanolic, benzene and aqueous extracts of leaf, stem and root of Olea europaea $L$

\begin{tabular}{|c|c|c|c|c|c|c|c|c|c|}
\hline \multirow{2}{*}{ Plant constituents } & \multicolumn{3}{|l|}{ Leaf } & \multicolumn{3}{|l|}{ Stem } & \multicolumn{3}{|l|}{ Root } \\
\hline & Methanol & Benzene & Aqueous & Methanol & Benzene & Aqueous & Methanol & Benzene & Aqueous \\
\hline Alkaloids & + & - & + & + & - & - & + & - & + \\
\hline $\begin{array}{l}\text { Carbohydrates and } \\
\text { glycosides }\end{array}$ & + & + & + & + & + & + & + & - & + \\
\hline $\begin{array}{l}\text { Phenolics compounds } \\
\text { and tannins }\end{array}$ & + & - & + & - & - & - & - & - & - \\
\hline $\begin{array}{l}\text { Proteins and amino } \\
\text { acids }\end{array}$ & + & + & + & + & + & + & - & - & + \\
\hline Flavonoids & + & - & + & - & - & - & - & - & - \\
\hline Terpenoids & + & - & + & - & - & - & + & - & + \\
\hline Saponins & - & - & - & + & - & + & + & - & + \\
\hline Phlobatannins & - & - & - & - & - & - & - & - & - \\
\hline Steroids & + & - & - & + & - & - & + & - & - \\
\hline
\end{tabular}

\section{Phytochemical Analysis of the Plant Extracts Olea europaea}

Different solvent of varying polarity were used for the extraction of the three parts of $O$. europaea for phytochemical analysis and the result of the extraction revealed the presence of various phytochemical constituents. Methanolic extract showed the presence of carbohydrate, glycosides, phenols, tannins, proteins, amino acids, flavonoids, terpenoids and steroids. While the benzene extracts carbohydrate, glycosides, proteins and amino acids are present. Aqueous extract showed the presence of alkaloids, carbohydrate, glycosides, phenols, tannins, proteins, amino acids, flavonoids and terpenoids. Stem extract of O europaea in methanol showed the presence of alkaloids, carbohydrates, glycosides, proteins, amino acids, saponins and steroids. Benzene extract of the stem showed the presence of carbohydrate, glycosides, proteins and amino acids. Whereas in aqueous extract saponins are also present with carbohydrate and proteins. Alkaloids, carbohydrates, glycosides, terpenoids, saponins and steroids were present in the methanolic extract of O europaea root. Aqueous extract showed the presence of alkaloids, carbohydrates, glycosides, proteins, amino acids, terpenoids and saponins while no phytoconstituents were found in the benzene extract (Table 4).

\section{Discussion}

In the present study we found that methanolic extract of $O$. europaea in combination of ampicillin shows higher zone of inhibition and lesser MIC values as compared to methanolic extract of leaves of $O$. europaea or ampicillin when used alone. Synergistic antimicrobial activity was found when methanolic extract of leaves of $O$. europaea was used in combination with ampicillin against against E.coli and P. aeroginosa $(\mathrm{FIC} \leq 0.5)$. Prostanthera species, like many other Australian plants, have been shown to have essential oils with potent antimicrobial activity. Essential oils from the desert species $P$. centralis have been shown to be effective against grampositive bacteria with MICs against $S$. aureus of approximately 0.1 $\mathrm{mg} / \mathrm{ml} .{ }^{14}$ On the other hand, streptomycin sulfate and chloramphenicol used as positive controls showed strong antibacterial activities against both Gram-positive and Gram-negative bacteria like as the results of previous studies. ${ }^{15}$

Partial Synergistic antimicrobial activity was observed against $S$. aureus. Methanolic extract of stem and roots of $O$. europaea in combination with ampicillin gave indifferent antimicrobial results $($ FIC $=1.0-4.0)$. Benzene extract of the leaf, stem and root of $O$. europaea in combination with ampicillin showed indifferent antimicrobial results $(\mathrm{FIC}=1.0-4.0)$. Aqueous extract of leaves of $O$. europaea in combination with ampicillin showed partial synergistic antimicrobial activity against $E$. coli, P. aeroginosa and $S$. aureus. (FIC $=0.5-1.0)$. All the plants parts were extracted with methanol, benzene and aqueous because these considered as the best solvent for the extraction of antimicrobial substances and may contain diverse chemical compounds with biological activity. ${ }^{16,17}$ Aqueous extract of the stem and root of $O$. europaea in combination with ampicillin showed indifferent antimicrobial results (FIC $=1.0$ 4.0). The alcoholic extract has greater effect as compared to Benzene 
and aqueous extract which may be due to the fact that alcohol is comparatively a better solvent as compared with water and benzene for extraction of phytochemical. ${ }^{18}$ Plants antimicrobials have been found to be synergistic enhancer in that they have little antimicrobial property alone but when they are taken concurrently with standard drug enhances the effect of antibiotics. ${ }^{19}$

Mechanism of synergy is still insufficiently researched. Some authors suggest that phytocompounds disturb cell wall or increase permeability of the cytoplasmic membrane and thereby facilitate the influx of antibiotics and produce efflux pump inhibitors. ${ }^{20}$ Differential antimicrobial activity of herbs against different bacteria might be due to present of different active phyto-compounds. Among those antimicrobial compounds phenolic compounds, terpenoids, and alkaloids are very important compounds in antimicrobial or antioxidant effects. ${ }^{21}$ The analysis of olive leaf extract allowed the identification of seven phenolic compounds caffeic acid, verbascoside , oleuropein, luteolin 7-O-glucoside, rutin, apigenin 7-O-glucoside and luteolin 4'-O-glucoside. ${ }^{22}$ This work confirms the antibacterial activity of $O$. europaea extract and shows their potential use as agents which enhance antibiotic activity.

\section{Conclusion}

In ancient and modern era, aerial parts of herbs have been generally used for the cure of crucial health care and variety of ailment across the world depends on geographical cultivation. Leaves of $O$. europea play a vital role in health care system due to containing of certain phytochemical. Overall results of current study reflect that highest antimicrobial activities were determined against Escherichia coli, Pseudomonas aeruginosa and Staphylococcus aureus. Among selected studied medicinal plant, O. europea leaf showed more antibacterial activity.

\section{Conflicts of interest}

There is no conflict of interest.

\section{Acknowledgements}

None.

\section{Funding}

None.

\section{References}

1. Bowler P, Durden B, Armstrong D. Wound Microbiology and Associated Approaches to Wound Management. Clin Microbiol Rev. 2001;14(2):244-269.

2. Church D, Elsayed S, Reid O, et al. Burn wound infection. Clin Microbiol Rev. 2006;19:403-434.

3. Gupta N, Gautam V, Saini S, et al. Prevalence of multi drug resistant organism in wound infection. $J$ Infect Dis Antimicrobial Agen.t 2002;19:111-117.

4. Esebelahie NO, Esebelahie FO, Omoregie R. Aerobic bacterial isolates from wound infection. Afr J Cln Exper Microbial. 2013;14(3):155-159.

5. Nichole RE. Preventing surgical site infection: a surgeon's perspective. Emerg Infect Dis. 2001;7(2):220-224.

6. Thomas KH. Surgical Wound Infection, an overview. Am J Med. 1981;70(3):712-718.
7. KC R, Shrestha A, Sharma VK. Bacteriology Study of Wound Infection and Antibiotic susceptibility Oattern of Isolates. Nepal Journal of Science and Technology. 2013;14(2):143-150.

8. Gottrup F, Melling A, Hollander D. An overview of surgical site infections: aetiology, incidence and risk factors. EWMA Journal. 2005;5(2):11-15.

9. Cheesbrough M. District Laboratory Practice in Tropical Countries. Part 2, Cambridge University Press, India. 2000:124-132.

10. CLSI. Performance standards foe antimicrobial susceptibility testing twenty-first informational supplement. 2011;31(1):M100-S21.

11. Magiorakos AP, Srinivasan A, Carey RB, et al. Multidrug-resistant, extensively drug-resistant and pandrug-resistant bacteria: an international expert proposal for interim standard definitions for acquired resistance. Clin Microbiol Infect. 2012;18(3):268-281.

12. Maharjan S. Bacteriology of Wound Infection Among patients Visiting B \&B Hospital and Antibiotic Sensitivity Profile of the Isolates. M.Sc. dissertation submitted to the department of Microbiology, Nepal. 2009.

13. Phuyal K. Bacteriology of Wound Infection with Reference to Multi Drug Resistant Isolates. M.Sc. dissertation submitted to the Department of Microbiology, Nepal. 2008.

14. Shrestha P. Bacteriology of Wound Infection and their Antibiotic Susceptibility Pattern. M.Sc. dissertation submitted to the Department of Microbiology, Nepal. 2018.

15. Acharya S. Multi Drug Resistant of bacterial Isolates from wound Infection. M.Sc. dissertation submitted to the Department of Microbiology, Nepal. 2012.

16. Bhattarai S. Microbiological Profile of Wound Infection and their Antibiotic Susceptibility pattern. M.Sc. dissertation submitted to the Department of Microbiology, National College, Kathmandu Nepal. 2013.

17. Yakha JK, Sharma AR, Dohal N, et al. Antibiotic Susceptibility Pattern of Bacterial Isolates Causing Wound Infection Amongthe Patients Visiting B \& B Hospital. Nepal Journal of Science and Technology. 2014;15(2):91-96.

18. Banjara MR. Study of Air, Water and Wound Infection in Different Wards of TUTH. M.Sc. dissertation submitted to the Central Department of Microbiology, Nepal. 2002

19. Hani AM, Adnan SJ. Incident of Pseudomonas aeruginosa in Postperative Wound Infection. Am J Infect Dis. 2009;5(1):1-6.

20. Ranjan KP, Ranjan N, Bansal SK, Arora DR (2011) Prevalence of Pseudomonas aeruginosa in Post-operative Wound Infection in a Referral Hospital in Haryana, India. J Lab Physicians 2 (2): 74-77.

21. Zafar A, Anwar N, Ejaz H. Bacteriology of Infected Wounds- A Study Conducted at Children Hospital Lahore. Biomedicavol. 2007;23:1.

22. Flagas ME, loannis AB, Sofia KK, et al. Outcome of Infection Due to Pandrug-resistant (PDR) Gram Negative Bacteria. BMC infect Dis. 2005;5:24.

23. Li XZ, Ma D, Livermore DM, et al. Role of Efflux Pump(s) in Intrinsic Resistance of Pseudomonas aeruginosa: Active Efflux as a Contributing Factor to $\beta$-Lactam Resistance. Antimicrob Agents Chemother. 1994;38(8):1742-1752.

24. Davis KA, Moran KA, McAllister et al. Multidrug Resistant Acinetobacter Extremity Infections in Soldiers. Emerg Infect Dis. 2005;11(8):1218-1224.

25. Brooks GF, Carroll KC, Butel JS, et al. Jawez, Melnick and Adelberg's Medical Microbiology. (24 th $e d n)$, MC Graw Hill Companies, New York, USA. 2007:263-270. 